\title{
INDIANS IN SILICON VALLEY: NETWORKS AND OPPORTUNITIES
}

\author{
P.A. Mathew*
}

\begin{abstract}
2.
ABSTRACT

The emigration of Indians to foreign countries especially U.S. was made possible because of the availability of talented and brainy students and professionals in India and the favourable immigration laws. The networking structure part of the silicon valley provided the Indians with ample cpportunities for wealth creation and to start new enterprises. It took some time for Indians to seize the opportunity. The hindrances encountered by the technocrats mainly emerged from the bureaucracy and the protectionism of the Indian market.
\end{abstract}

The Indian diaspora had been spreading like a "banyan tree" from South Asia to all over the world for more than 2000 years. The spread of the Indian diaspora can be seen in three sequential phases in global historical terms. The first phase was during the ancient and medieval period, when contacts were established with Northern Africa and South East Asia. The second phase occurred during the colonial period in the $19^{\text {th }}$ century. The third phase of the migration has taken place in the present century to the industrially developed countries of the West.

* Lecturer, Dept. of Management Studies, Christ College, Banglore. 
Although Indians started to reach North America as early as 1750 it was the Immigration Act of 1965 which was the turning point in the flow of Indians to the US, as India became one of the major beneficiaries of this Act. Starting with 582 Indians in 1965, the number increased to an annual average of 20,000 in the post- 1975 period.

Indian immigration during this period reflected and represented more of urban India and nearly consisted of all religious and linguistic groups. One of the most important characteristics of this group was that most of them were fluent in English which facilitated their adjustment and adaptation to the American way of life to great extent

\section{Indian Immigration and Restructuring}

The large scale immigration to the West from Asia, especially India after 1965, is both an economic and political phenomena. Asian immigrants to the US during this period had a dominant role in the economic restructuring of the US in terms of providing labour, skills and entrepreneurial energy. Some were hired, often through direct recruitment, to fill critical shortages and this was especially true for highlyskilled occupations requiring advanced education. The lack of adequate funds for advanced training, the tendency of some of the best students to pursue high salary jobs in the financial and legal sectors, and the inability to alleviate oppressive working conditions had produced a shortage of personnel in the US in health, engineering and scientific fields. Professionally trained Asian immigrants, especially Indians were able to offset and deal with these shortages and drawback. ${ }^{2}$

This was largely possible because of the investments made by the Asian countries like India on education, especially of technological education. As part of the effort to move up the ladder of technological innovations, the Indian government promoted higher education. Some students were sent to the US for advanced training, others were trained at home, often in institutions developed under the ageis of advanced capitalist countries. Because of this a highly trained structure of trained technicians and professionals exists in many Asian countries especially in India.

However, Asian countries like India also suffer from internal contradictions, in terms of being unable to absorb their own highly trained personnel. Cheap labour policies have restricted social spending and therefore reduced the demand for certain kinds of social services. Another factor is the limited numbers of opportunities available in the private sector. Countries such as the US offer much higher salaries or more profitable investments than the home country. Finally, the professionals 
and managers share the capitalist ideology of individualism, which makes them put their own career first rather than show concern for national welfare. This dualism creates a contradiction in both the sending and the receiving countries - home countries like India produces more highly-trained numbers than they can absorb, while the US produces fewer than it needs. ${ }^{3}$

The requirement for highly skilled labour in the US reflected the growing technological complexity in production. Work became more fragmented and specialized, encouraging the emergence of a large, technologically-based and university-trained professional class. Military and industrial considerations also induced a shift in occupational needs. The contributions of foreign scientists to the construction of the atomic bomb and later the development of rocketry, proved that highly educated immigrants were crucial in the process of building a technological lead in military affairs. Industry shared the need for highly educated labour. The major problems facing the industry were the scarcity of enginnering personnel in the face of rising demand. In the case of the health sector, proliferation of private health insurance generated an enormous demand for health practitioners. In this way, because of the international disparity, the rewards of labor, greater availability of high wages and professional opportunities, provided the 'pull' of material incentives for the Indians to emigrate while the 'push' arose from the inability of India to absorb thiose with high education levels into its own markets

The increase in the need for educated technical manpower led to the revision of the immigration laws in the 1990 Immigrations Act. It was based on a new preference system based on three tracks, for family sponsored, employment based or/and university immigrants. This benefited the educated immigrants because segregating the employment based preference meant that the availability of occupational visas was no longer dependent on the number of people admitted as family immigrants. The 1990 Act also increased the number of occupational immigrants and their families from 54,000 to 1,20,000 with 80,000 for high level professionals and families. This act elevated the position of employers who had become dependent on the immigrant and temporary foreign labor, particularly in hospitals, research universities and high tech firms. ${ }^{4}$

\section{Silicon Valley, information technology and Indians}

The power and influence of the Indian s today is more apparent in Silicon Valley, the mecca of the information revolution, than in any other place in the US. The information revolution has been brought about, among other things, by the development of microprocessor based, user-friendly home computers and global 
satellite communication. The marriage between the two produced, in the seventies, a new communication science known as 'informatics'. From high frequency wireless communication to digital compression technology, to microwave communications, to silicon chips, to satellite communication, to optic fibre and then to telematique and computer to computer communication at very high speed - there has been a tremendous revolution in information technology. In the twenty first century information technology, broadly defined, is likely to be the most important power resource. ${ }^{5}$

Two distinguishing characteristics of the Silicon Valley, were the unusually large supply of scientific and engineering manpower coming out of universities, research institutions and laboratories here, and the huge market for semi-conductors generated by the defence and aerospace contracts, directed to the region. One distinguishing aspect of Silicon Valley is, that it supports open labour markets. In this case, Silicon Valley as a whole rather than the individual firm defines opportunities for individuals. Collective advantages of regional, rather than firm-based labour markets, lie in the multiple opportunities they provide for learning. As individuals move between - firms and industries, learning occurs through acquiring new skills, experiences and knowhow. It occurs as they, along with teams of entrepreneurs, regroup to experiment with new technologies and applications. Learning occurs as firms of different sizes and specialisations jointly solve common problems and analyse failures. In short, learning in Silicon Valley is a collective process that is rarely confined within the boundaries of individual firms. Resources are drawn from the region as a whole. It thus epitomises 'the boundary-less career. ${ }^{\prime 6}$

Another crucial element in the labour market behaviour is the social embeddedness of labour markets. The region's dense social and professional networks function as highly efficient job search networks, contributing to unusually high rates of inter firm mobility in the region. Engineers in Silicon Valley have shifted so frequently between firms, that mobility has not only became socially accepted, it also has become a norm. The region's engineers developed loyalties to each other and to advancing technology, rather than to individual firms or even industries. The geographic proximity of firms in Silicon Valley facilitated these high levels of mobility. In this way moving from job to job in Silicon Valley did not disrupt personal, social or professional ties as much as it could elsewhere in the country. Local technology companies in turn competed intensely for experienced people.

As individuals move from firm to firm, their paths overlap repeatedly but professional loyalties and friendships survive during these changes. Few presume that the long term relationship needed for professional success will be found within the four walls of any particular company. Social and professional networking is maintained and 
extended through informal social gatherings, trade shows etc. Informed exchange and collaboration thus coexist with fierce inter firm competition in Silicon Valley, to support careers that are rarely confined to individual companies. ${ }^{7}$

As individuals change project teams and companies in an open labour market like Silicon Valley, they also blur the boundaries between firms and the institutions of the surrounding community, thereby undermining the distinction between work and social life and between economy and civil society. To advance higher of the career graph, individuals in Silicon Valley rely on the contacts they establish in bars, health clubs, hobby clubs, technical and professional associations, training programs community colleges, universities and a variety of other networks that cross company lives and reach from the economy into social and even family life. As a result, the success of local firms is linked to the reinvigoration of the local community. ${ }^{8}$

The Indians were typically from a newly immigrant middle class who arrived as students for higher studies. These highly motivated students excelled in the new environment, and usually stayed on after graduation. Working up the professional echelons as technocrats through the seventies, they were generally very focused on career, education and family. They reached the highest levels of their professions as engineers, scientists, professionals and financial managers. ${ }^{9}$ The new set of immigration laws since 1965 benefited the Indians by increasing the opportunities available to them in the US for pursuing education and finding employment. The number of immigrant engineers also increased in good numbers due to the increase in the number of graduates who emerged from the newly set up educational institutions, specializing in engineering in the sixties and early seventies in India.

The contributions made by the Indian Institutes of Technology (I.I.T) in producing engineers of repute cannot be overlooked. The, I.I. Ts which were established after independence, with the support of western countries such as the US, USSR, and Canada were institutes of premier learning and produced internationally competitive engineering graduates. Due to both 'push' and 'pull' factors mentioned earlier most of them emigrated to the US to continue their post-graduate studies. Along with the I.I.Ts there were also institutions run by state governments and private agencies imparting technical education and producing equally good engineers. After completing their education, some of them found jobs both in the private and public sectors. Many however decided to go abroad for higher education. Due to language barriers countries like Germany did not find favours with Indian graduates. The US was the favourite location both on account of the absence of language barriers and due to the opportunities it offered. The relaxation of the immigration laws were utilized by the immigrants to locate themselves in premier universities in America. Over the years, Indian-American engineers who graduated from 
technology institutes in India and who completed their advanced degrees in American universities are being recognised as an increasingly significant force in Silicon Valley. ${ }^{10}$

\section{Networking as a Factor of Growth}

The social embeddness of the labour markets and close social and professional networks in the Silicon Valley has been discussed earlier. Indians in Silicon Valley are among the most highly networked of communities. Networks have played a key role in helping migrants from India in emerging as top players in Silicon Valley. Indians who live in the Bay area and work in the high tech industries, have formed an amazing web. Indians invest in one another's companies, sit on one another's boards, and hire each other in key jobs. Many live in close proximity and have similar kind of social living. " Attracted by the booming economy of the 90 s and proficient in high technology areas, they have been able to create companies that push aggressively into the business mainstream. Out of the 750 companies operated by Indians many have become successful because of good networking.

The wealth creation potential of the network is huge. Naturally, it was only a matter of time, before the Silicon Valley's money establishment (Venture Capitalists) discovered it. The venture capitalist (VC) has realised that Indians are not only some of the best entrepreneurs, but they are also wired into one of the valley's most precious resoures - technical talent. Companies with Indians as founders, especially those who studied in IIT's, can hire teams of developers faster than the average company. This is undoubtedly a great advantage in the age of high competition. ${ }^{12}$

At the heart of this network, is a group of highly successful businessmen who are recycling their profits and the lessons they have learned by mentoring a new generation of Indian emigrants. These investors critique business plans, provide seed capital and offer advice to the young Indian entrepreneurs. ${ }^{13}$ The Indus Entrepreneurs (TIE), is an organisation founded in Silicon Valley by entrepreneurs from South Asia engaged in information technology and other high tech industries like bio-medical services and consultancies.

\section{Diaspora and its Linkages with India}

The increased linkages with India and its diaspora in the US and especially Silicon Valley has been more in the case of Information technology. Contribution of the diaspora in this has been indirect and not very prominent in the early stages but 
they contributed more as decades progressed. Policy formation to a large extent was facilitated by the increasing network between the policy makers and the diaspora.

The Information technology emerged in India during the early 1960's and software firms took root in the mid-1970s. The growth has been phenomenal since mid 1980. In 1990, India's high tech industries generated software and computer related services worth \$150 million. Today they contribute a significant part of India's expotrs.

The development of the computer software industry can be divided into three phases. ${ }^{14}$ The first phase began with the presentation of the Bhabha Committee Report in 1966 and lasted until the late 1970s. The focus during this period was on the hardware segment. The second phase began with the adoption of the 1978 computer policy which marked the entry of the private sector into hardware and in a limited way into the soffware sector. The state-owned computer firms thus lost their monopoly. The third phase began in the mid 1980s, which when the software industry took off entered a high-growth period.

The 1978 policy, for the first time, noted the importance of the diaspora in this sector and emphasised that those willing to return and invest in minicomputers related programs will be promoted. ${ }^{15}$ The crucial consequences of the 1978 policy was that, it initiated a series of developments that profoundly altered the structure of the industry by the mid 1980s. This policy led to the entry of small and mediumscale computer professionals/entrepreneurs from India and abroad, into the soffware and hardware industries. A large majority of software entrepreneurs were engineers and science graduates. The Indian computer industries, which had stagnated in terms of production and technology began to take off. ${ }^{16}$

Although private software manufacturers were encouraged as early as 1970 , few entrepreneurs came forward, because of complicated bureaucratic procedures, lack of incentives for export and low domestic demand. This changed in the late 1970s because of the growth of the private hardware segment and restrictions on the import of software, which ensured a growing demand for indigenous software. Further, since software exporters were permitted to import hardware of lower import duties in return for meeting export targets, software entrepreneurs began focussing on both the domestic and international market. New entrants into the software segment included Infosys, Mastek, Integra Micro System, Kirloskar computer services etc. These companies had to interact with the Department of Electronics, to acquire licenses to begin production and import the necessary hardware for software production and export. The Policy makers in the Department of Electronics were interacting with the diaspora in Silicon Valley. This interaction played a crucial role in the subsequent development of the computer software policy. 
Both formal and informal interaction between officials, entrepreneurs and successful technocrats in Silicon valley were crucial in fostering a new environment. Similar professional and class backgrounds were central to this process of interaction and the two were linked by educational and even social ties. The new computer entrepreneurs were graduates of engineering colleges such as Indian Institutes of Technology, the Indian Institute of Science and American and European universities. A number of the technocrats of the Department of Electronics also had similar educational backgrounds. The Indians were making a mark in Silicon Valley during this period of time too. This facilitated informal relations between the officials ,entrepreneurs, and the diaspora which transformed the process of policy formulation. Long tenures of the officials ensured the emergence of network ties between the three and it deepened over a course of time.

The personal initiative taken by the then prime minister of India, Rajiv Gandhi, helped to foster greater autonomy of the Department of Electronics. Contribution of Sam Pitroda -US returned professional in fostering an increased linkages between Silicon Valley Indians and the policy making in India is again an important factor. The growth of the industry was also facilitated by various other factors.

The pattern of informal interactions developed during the 1980's with software entrepreneurs and the successful Indians in Silicon valley helped the officials understand the needs of the industry. The pattern of interaction was facilitated by the industrial associations like NASSCOM too. However, the most important factor was the role played by the networking between local industrialists-Silicon valley Indians and bureaucrats of the Department of Electronics. These non-contractual ties provided an additional avenue for interaction, discussion and persuasion. With little interest in a protected market, and having channels through which these demands could be articulated successfully, the software manufacturers had little interest in establishing clientelistic relations with the Department of Electronics bureaucrats. While the autonomy achieved during Rajiv Gandhi's leadership aided the policy changes in the mid 1980s, it enhanced embeddness. More ties and channels of communication by the Department of Electronics within the state apparatus, facilitated the changes, and non-contractual ties with the software entrepreneurs took the computer industry to admirable heights.

The Indian diaspora in Silicon Valley who have made it to the top of the Information technology Industry during the technological boom, is paying back the country in different ways. Five Indian Americans have proposed to collect US $\$ 1$ billion to set up a series of private research institutions in India, to be called Global Institutes of Science and Technology (GIST). The promoters want to create six world class centres of excellence in education and research. The focus of the research will be "sunrise" disciplines such as life sciences, material sciences and on internet and computing. 
These institutions will be able to act as an active incubator around which companies can mediate in the new economy. ${ }^{17} \mathrm{Kanwal} \mathrm{S}$. Rekhi, the brain behind the Indo-US Entrepreneurs, donated $\$ 5$ million to the Indian Institute of Technology, Bombay, to start a new school for information Technology. There are many contributions like this and over the years the flow is increasing.

\section{Concluding Remarks}

Although India's computer industry has emerged as a success in lot of ways, what is required is more investments from the Indian diaspora. Two factors have hindered the prospects. As seen earlier, there was intense network relationship amoung Indian diaspora in Silicon Valley which made them a rather self contained group and (2) Indian Industrialist entrepreneurs and the officials of the Department of Electronics. These two developments were instrumental in developing the Industry and improving the prospects of Indians. Although Silicon Valley Indians have played a limited role in formulating policies it did not lead to an increased flow in terms of investments. In other words the network relationship in terms of entrepreneurship did not cross borders, inspite of the fact that many of the Indian diaspora had their initial education in technology institutions in India. Indian government policies were more or less limited to the Indian players in the domestic arena. Diaspora in the Silicon Valley in turn did not realise the full potential of India and were discouraged by the lack of success in earlier ventures. One of the crucial factors for the success of the Indian diaspora was the availability of venture capital. Organisations like Indus Entrepreneur were able to meet this demand in Silicon Valley and this was a crucial role in their success. The Indian government needs to foster US style venture capital, so that India will become a haven for startups especially from the diaspora.

In the macro environment the appointment of the parliamentary committee on Indian Diaspora and its report has done lot in terms of looking at the diaspora in the US and the involvement of Silicon Valley Indians. With suitable policy directions their involvement is expected to be more in the years to come. 


\section{Bibliography}

1. Annalee Saxeman, "Beyond Boundaries: Open labour markets and Learning in Silicon Valley" in Michael B. Arthur and Denise M. Rousscau (ed), The Boundary less career: A New Employment Principal for a New Organisaional Era (New York, Oxford University Press, 1990)

2. M. Alembic Warner, "The Indians of Silicon Valley" www. http fortune.com. Vol. 141, No. 10, May 15, 2000.

3. Hugh Tinker, The Banyan Tree:Overseas Emigrants From India, Pakistan and Bangladesh (London, Oxford University Press, 1977)

4. Indus Immigrants in America. www:http:indus entrepreneurs.com

5. Murray Hubert,' Guiding Lights' www.Far Eastern Economic Review.Com, Oct 19, 2001. Vibha Pingle, "Rethinking the Developmental State" (New Delhi, Oxford University Press, 1999). P. 122. Department of Electronics Mini computer policy 1978.

6. Paul Ong, Edna Bonacich and Lucie Ching, (ed) "The Political Economy of Capitalist Restructuring and New Asian Immigration" in The New Asian Immigrations in Los Angles and Global Restructuring (Philadelphia, Temple University Press, 1995).

7. Pallava Bagla 'Pay Back Time: India Reaps Brain. Drain dividend, National Geographic.com, Oct. $4^{\text {th }}, 2000$.

8. Robert O. Leoham and Joseph S. Nye, "Power and Interdependence in the Information Age' Foreign Affairs, vol.77, no: 5 Sep/Oct 1998.

9. "Staying away - India woos its Diaspora in Silicon Valley," Far Eastern Economic Review, July 101997.

10. S.S. Oberoi and G.V. Ranganathan, "Indian Software Scenario" Electronics-Information and Planning, 


\section{End Notes:}

1 Hugh Tinker, The Banyan Tree:Overseas Emigrants From India, Pakistan and Bangladesh (London, Oxford University Press, 1977 )

2 Paul Ong, Edna Bonacich and Lucie Ching, (ed) "The Political Economy of Capitalist Restructuring and New Asian Immigration" in The New Asian Immigrations in Los Angles and Global Restructuring (Philadelphia, Temple University Press, 1995) p. 33

3 Paul Ong, etal 1995 pp. 26-27.

4 Ibid. p. 64.

5 Robert O. Leoham and Joseph S. Nye, "Power and Interdependence in the Information Age' Foreign Affairs, vol.77, no: $5 \mathrm{Sep} / \mathrm{Oct}$ 1998, p.87.

6 Annalee Saxeman, "Beyond Boundaries: Open labour markets and Learning in Silicon Valley" in Michael B. Arthur and Denise M. Rousscau (ed), The Boundary less career: A New Employment Principal for a New Organisaional Era (New York, Oxford University Press, 1990)

7 Ibid. p.9-10.

8 Ibid. p.19.

9 Indus Immigrants in America. www:http:indus entrepreneurs.com

10 "Staying away - India woos its Diaspora in Silicon Valley," Far Eastern Economic Review, July 10 1997. p. 69.

1 Ibid.

12 M. Alembic Warner, "The Indians of Silicon Valley" wnw .http fortune.com. Vol. 141, No. 10. May 15, 2000.

13 Murray Hubert,' Guiding Lights' www.Far Eastern Economic Review.Com, Oct 19, 2001.

14 Vibha Pingle, "Rethinking the Developmental State" (New Delhi, Oxford University Press, 1999). P. 122.

15 Department of Electronics Mini computer policy 1978

16 S.S. Oberoi and G.V. Ranganathan, "Indian Software Scenario" Electronics-Information and Planning, Aug, 1991, p.603.

17 Pallava Bagla 'Pay Back Time: India Reaps Brain. Drain dividend, National Geographic.com, Oct. 4th, 2000. 